\title{
斜面崩壊防止のための信頼性設計に関する研究 STUDY ON RELIABILITY-BASED DESIGN FOR PREVENTION OF SLOPE FAILURE
}

\author{
松尾稔* ・上 野 誠** \\ By Minoru MATSUO and Makoto UENO
}

\section{1.はじめに}

集中豪雨による斜面崩壊が多大の災害を生むことは周 知の事実であり，従来から，現象の解明と対策に関して 多くの努力が払われてきた. 災害を工学の対象とすると き，そのアプローチには 2 つの側面がある. 1 つは災害 の予知問題であり，他の 1 つは予測される現象がもたら す災害を事前に防止するための手段決定の問題である. 本論文は，防止手段決定のための一方法論を提示するこ とを目的としている.

豪雨による斜面崩壊問題の科学的アプローチは, 他の 土木構造物の問題に比べてむずかしい面が多い.なぜな ら，対象があまりに大きな広がりを有し，しかも斜面の 幾何学条件, 植生, 土質などが種々雑多だからである. 土質調査 1 つっても，危険と思われる膨大な数の全斜 面に対し, ボーリングを伴う精密な調査, 試験を行うこ となど, 現実には不可能である.この研究では, 多少粗 くなっても，かなり広範用の一般的な斜面に適用可能な 方法論の開発を意図している（もちろん，精密な調査や 研究が可能な特定の斜面を対象とする場合にも, 適用可 能であることはいうまでもない). したがって，土質の 把握 1 つにしても，できるだけ簡単な試験で判断が可能 な方向性を狙っている. このことは, 当然, 力学的には ある種の粗雑さを許容することにつながるが, 精密では あっても, 実行不可能な, 非現実的な議論よりも, 工学 に寄与できるのではないかと考えている．このような趣 旨をふまえて，本論文では以下のような順序で研究を進 めている. すなわち，(i) 雨による斜面土の力学的特性 の変化の推定, (ii) 雨量から土中水分（飽和度）の推 定, (iii) 降雨による斜面の破壊確率の変化の推定, (iv) 信頼性設計 (Reliability-based design) の考え方による

* 正会員 工博 名古屋大学教授 工学部土圧研究施設

** 学生会員 工修 名古屋大学大学院工学研究科博士課程 斜面崩壊防止手段の決定法の提示，（v）この方法論を実 際に適用した事例研究の提示.

なお, 本研究では, 岩盤斜面や深い特殊な崩壊は取扱 わない. 斜面崩壊の中でもっとも多い, 比較的浅い部分 での土砂のすべり破壞を対象としている。

\section{2. 水分変化に伴う土の強度の遷移特性}

不飽和状態の土の力学的特性は, 土中の水分状態に強 く依存する. 斜面表土のように降雨による水分変化が著 しい地盤の安定問題では, 土の強度の遷移特性を明らか にすることが重要である.ここでは土の強度を表わすパ ラメーターとして, 粘着力 $c$ と, せん断抵抗角 $\phi$ を取り 上げ，土の飽和度 $S_{r}$ との関係を議論する. 特に, 斜面 安定に大きく寄与するみかけの粘着力 $c$ の含水比増加に よる遷移特性を，重点的に考察する．なお，ここでは， 降雨時の一般的な斜面崩壊を問題にしているから，いわ ゆる山土を対象とするのであり, 完全な砂や粘土は取扱 わない.

\section{（1） $\boldsymbol{c} \sim \boldsymbol{S}_{r}$ 関係}

鬼塚によれば1)，毛管水の働きにより土粒子間に圧縮 力が生じ，これがインターロッキングと同様な働きをす ることによってみかけの粘着力が生ずる．そして，この 粒子間圧縮力はある飽和度で ピークを示す．換言すれ ば, みかけの粘着力 $c$ も， ある飽和度 $S_{r}$ でピークを 示すはずである. 一般的な斜面で普通に遭遇する数種の 土（表一1）について実施された力学試験結果 ${ }^{1), 2)}$ を $S_{r}$ 図上で再整理すると, すべての場合に, $c$ にピーク が現われている. 図一1 はその一例である.表一1 から わかるように，図一1 の場合も含めて，試験はほとんど すべて排水条件で行われている. そこで, 間隚比 $e, S_{r}$ に関する整理は, せん断開始前の初期 $e, S_{r}$ 值に対し て行われる.このことは以下すべて同じである.さて， 
表一1 各土貿の物理 保数

\begin{tabular}{|c|c|c|c|c|c|c|c|c|c|c|}
\hline 土望番号 & 土の種類 & 比 $G_{s}{ }^{\text {重 }}$ & $\begin{array}{c}\text { 最適含水比 } \\
w_{0 p t}(\%)\end{array}$ & $\begin{array}{c}\text { 最大乾燥密度 } \\
(r d)_{\max }\left(\mathrm{t} / \mathrm{m}^{8}\right)\end{array}$ & $\begin{array}{c}50 \% \text { 粒 征 } \\
d_{30}(\mathrm{~mm})\end{array}$ & $\begin{array}{c}\text { 均 等 係 数 } \\
U_{c}\end{array}$ & 試験の種類 & 試 & 験 & 者 \\
\hline soil-1 & シルト蜇砂 & 2.68 & 15.5 & 1.79 & 0.37 & 134 & 一面せん断 & 渡 & 橋- 夜 & 久 \\
\hline soil-2 & ンルト筫砂 & 2.62 & 15.9 & 1.77 & 0.40 & 63 & 一面世人断 & 渡 & & 橋 \\
\hline soil-3 & ンルト質砂 & 2.69 & 11.9 & 1.94 & 0.48 & 70 & 一面せん断 & 桑 & 原 - 倉 & 石 \\
\hline soil-4 & ンルト質砂 & 2.62 & 15.9 & 1.77 & 0.42 & 65 & 一面せん断 & 松 & 尾·黒 & 田 \\
\hline soil-5 & 金黅マサ土 & 2.65 & 16.0 & 1.73 & 0.26 & 100 & 三軸国：椎 & 鬼 & & 嚓 \\
\hline soil-6 & 砂質口ーム & 2.63 & 23.6 & 1.59 & 0.24 & 188 & 一面世人断 & I: & 野・服 & 部 \\
\hline soil-7 & 口 - 厶 & 2.61 & 20.4 & 1.65 & 0.075 & $\cdots$ & 一面比人断 & I: & 野·服 & 部 \\
\hline
\end{tabular}

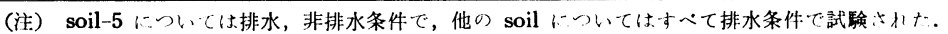

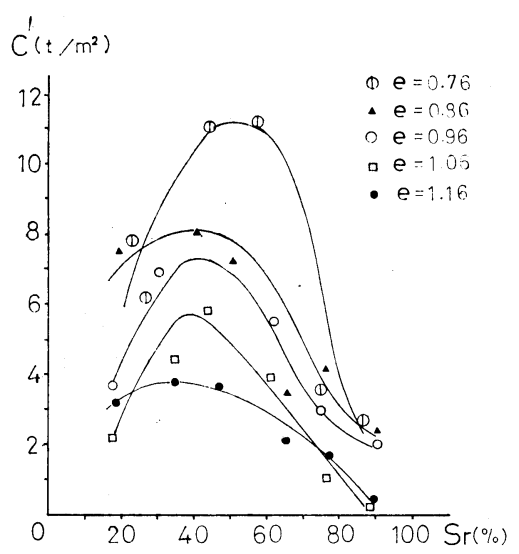

図一1 c $S_{r}$ 関係の 1 例 (soil-6)

$c$ が最大值 $c_{\max }$ となるときの飽和度を $S_{r}{ }^{*}$ とし, $e$ と $S_{r} *$ の関係を調べると, 図一2 のように直線的減少 関係となる. そこで, $S_{r} *$ の值が 図一2 の実線で表わ される平均值線 $\mu_{S_{r}{ }^{*}}$ のまわりに, 分散 $\sigma_{S_{r^{*}}}{ }^{2}$ で正規分 布すると考えると, $e$ が与えられたときの $S_{r}{ }^{*}$ の推定 分布の確率密度関数 (pdf) は,

$$
\operatorname{pdf}\left(S_{r} * \mid e\right)=\frac{1}{\sqrt{2 \pi} \sigma_{S_{r^{*}}}} \exp \left\{-\frac{\left(S_{r^{*}}-\mu_{S_{r^{*}}}\right)^{2}}{2 \sigma_{S_{r^{*}}{ }^{2}}}\right\}
$$

によって表わされる.

\section{(2) $\left(c / c_{\max }\right) \sim\left(S_{r}-S_{r} *\right)$ 関係}

実際問題としては, 飽和度が $S_{r}{ }^{*}$ より小さい範囲で は斜面安定上の 問題はほとんどない. そこで, 湿潤側 $\left(S_{r}>S_{r}{ }^{*}\right)$ について, 各土質の $c / c_{\max }$ ( $c$ は $S_{r}$ に対 応する粘着力）と $S_{r}-S_{r} *$ の関係を整理すると図一3の よ5になる. 図一3 より, ばらつきはあるが, $S_{r}$ の増 加につれて $c$ の值が低下することがわかる. $c / c_{\max }=$ $c^{*}$ とおき, $S_{r}-S_{r} *=\Delta s_{r}$ とすると, $c^{*}$ と $\Delta S_{r}$ には平 均的にみて直線関係が見出され, 図一3 の実線で示され る. 図-4に $c^{*}$ の平均值線のまわりのばらつきを示す. この図より, $c^{*}$ も平均值線のまわりに正規分布すると 考えることは妥当であるから，次式が成り立つ.

$$
\operatorname{pdf}\left(c^{*} \mid S_{r} S_{r} *\right)=\frac{1}{\sqrt{2 \pi} \sigma_{c} *} \exp \left\{-\frac{\left(c^{*}-\mu_{c} *\right)^{2}}{2 \sigma_{c} *^{2}}\right\}
$$

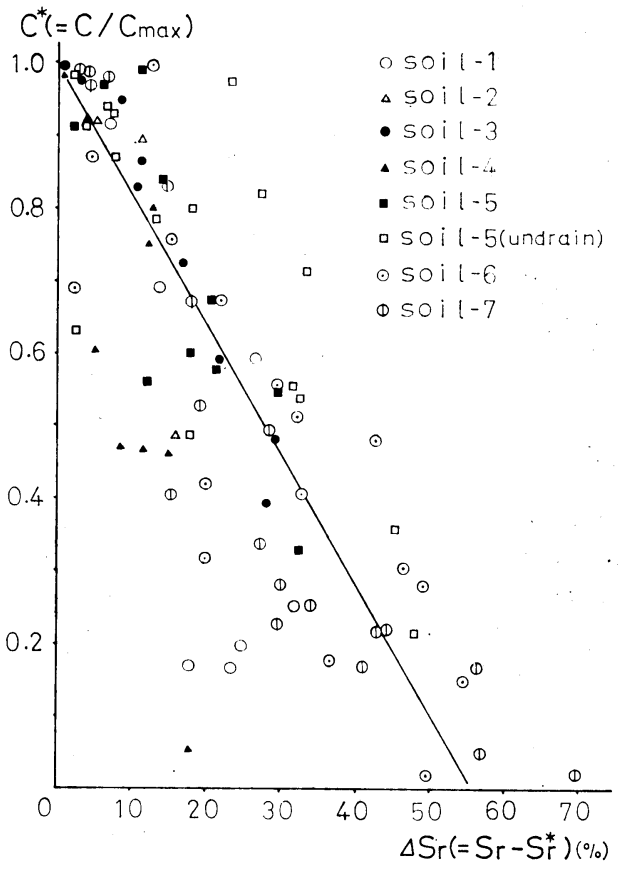

図一3 $\quad c^{*} \sim \Delta S_{r}$ 関係

ここに, $\mu_{c} *$ は $c *$ の平均值で, 図-3 の場合,

$$
\left.\begin{array}{l}
\mu_{c} *=1.0-0.018 \Delta S_{r} \\
\sigma_{c} *=0.182
\end{array}\right\}
$$




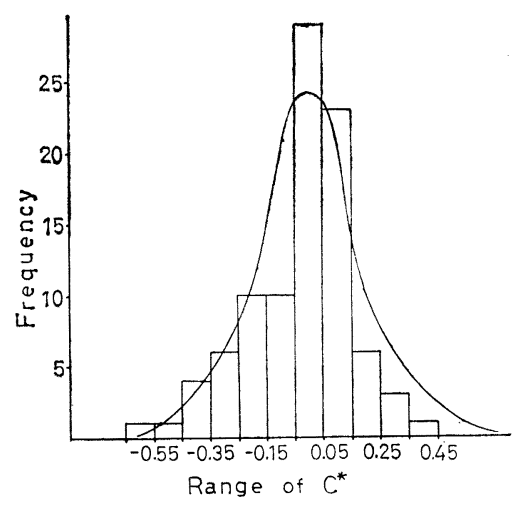

図一4 平均値線のまわりの $c^{*}$ のばらつき

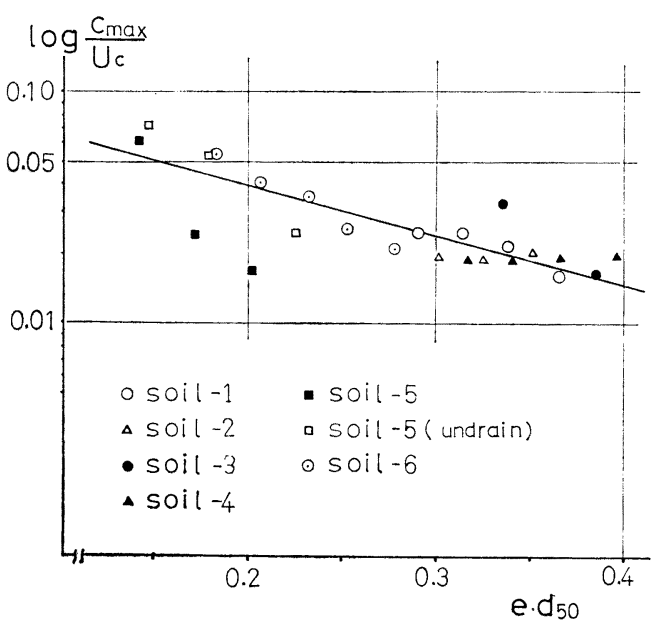

図-5 $e \cdot d_{50} \sim \log \frac{c_{\max }}{U_{c}}$ 関係

\section{(3) $c_{\max }$ 値の推定}

$c_{\max }$ 值は，毛管圧縮力に支配されるはずであるから， 土の間隙径, 土粒子の接触面積に関係する均等係数 $U_{c}$ の関数で表わされると予想される. そこで, 間隙径に関 連する因子として $e \cdot d_{50}\left(d_{50}\right.$ は $50 \%$ 粒径）を選び, $\log \left(c_{\max } / U_{c}\right)$ との関係を調べると図一5のようになる. これより $c \sim \phi$ 系の不飽和土では, $\log \left(c_{\max } / U_{c}\right)$ と $e$. $d_{50}$ に直線関係が存在することがわかる. 飽和粘土にお いて, $\log c_{u}$ と $e$ に線形関係があることはよく知られ ているが, 不飽和な $c \sim \phi$ 系の土でも類似した関係が見 出されたことは非常に興味深いことである. 図一5 と表 ー1 からわかるように, マサ士（soil-5）のような特殊 土を除けば, 各点は図一5 の直線上によくのっている. さらに, これらのばらつきが後の解析結果に及ぼす影響 は, 比較的小さい. いいかえると,これらのばらつきを 確率分布で表現しても, 解析をいたずらに困難にするの みであり, 工学的なメリットが少ないため, ここでは近 似的に以下の式を用いる.

$$
c_{\max }=0.103(0.0086)^{e . d 50} \cdot U_{c}\left(\mathrm{t} / \mathrm{m}^{2}\right) \cdot
$$

なお, $d_{50}$ は $\mathrm{mm}$ 単位である.

\section{（4）力学試験によらない $\boldsymbol{c}$ の推定}

以上の結果から, 物理係数 $e, d_{50}, U_{c}, S_{r}$ が与えら れれば, 力学試験によらずに $c$ の值が推定できることに なる. 推定される $c$ の分布は, 式 (1), (2) の積を $S_{r}$ * の確率空間 $(-\infty,+\infty)$ で積分したものに $c_{\max }$ 值を かければよいわけである（以下, 表示の簡単化のため式 (1), (2) の pdf を $\mathrm{f}$ と書く). すなわち, $\left(e, S_{r}\right)$ と いう状態量が与えられたときの, $c$ の確率密度関数 $\mathrm{pdf}$ $\left(\mathrm{c} \mid \mathrm{e}, S_{r}\right)$ は, 次式で与えられる.

$$
\begin{aligned}
& \operatorname{pdf}\left(\mathrm{c} \mid \mathrm{e}, S_{r}\right) \\
& \quad=c_{\max } \int_{-\infty}^{+\infty} f\left(S_{r} * \mid e\right) f\left(c^{*} \mid S_{r}, S_{r} *\right) d S_{r} * \ldots(5)
\end{aligned}
$$

式（5）において，物理的に考えれば $S_{r} *$ の範囲は $[0,100]$ となるべきであり, $(-\infty, 0],[100,+\infty)$ の 範囲注存しないはずである.しかし, 図一2 に示され るように $S_{r}{ }^{*}$ がこの両すその領域 $(-\infty, 0],[100,+$ の) に含まれる確率は非常に小さく, 他の土質諸係数 $c$, $\phi$ と同様に, この両すその部分は後の解析の結果にまっ たく影響しない. なぜなら, われわれの扱っている決定 上の破壊確率 $P_{F}$ が大きいからである. したがって, 式 (5) を $(-\infty,+\infty)$ の区間で積分しても，[0,100] の区間で積分しても結果にほとんど影響しないから， $S_{r}$ *を正規分布と仮定したつごう上, (5) の積分範囲を $(-\infty,+\infty)$ とおいたわけである.

式 (5)による推定分布に関し, 一面せん断試験結果か ら得られた実験值の分布と比較した一例を図一6に示 す. 飽和度が低くなるにつれて, 両者の適合度は高くな り, 特に $S_{r}$ の低い範囲ではほぼ完全に一致している. $S_{r}$ の高い状態では, 式 (5) による推定值の分散が実験

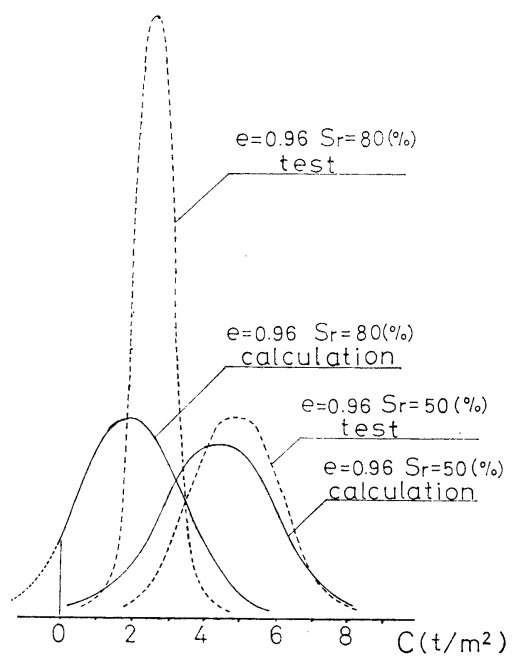

図一6 粘着力の推定分布と実駼結果の比較例（soil-6） 
值より大きくなるが，このことは後に示される破壊確率 を実際より大きく見積ることになり, 設計上は安全側で ある、なぜならば，後でのべるが，破壊確率とは安全率 の分布が 1 以下となる確率と定義されるものであり， $c$ のばらつきが大きいほど安全率のばらつきも大きくなっ て, 結局, 破壊確率を大きく評価することになるからで ある。

さて,このように力学試験によらずにかなりの精度で $c$ の分布が推定でき, しかもそれが任意の $S_{r}$ について 可能であるということは，斜面問題を考えていくうえで 非常に有効である. $e, d_{50}, U_{c}$ は, 簡単な土質調査や試 験から求めてもよいし, 観察をもとに推定してもよい. また， $S_{r}$ は降雨時の 斜面内浸透解析 ${ }^{3}$ から求めてもよ いし, 経験に基づく推定も可能である.ささら, 特別に 重要度の高い特定斜面を対象にするときには, 詳細な調 查, 試験からこれらの係数やあるいは $c$ の分布それ自体 を決めればよい. 要するに, 要請される実務のレベルや 範囲, 精度などに相応して, 弾力的に考えていけばよい のである.

\section{（5） $\phi$ の遷移特性}

図一7に $\phi$ と $S_{r}$ の関係の一例を示す.この図より， $\phi$ と $S_{r}$ の間には一般に負の相関があるが， $S_{r}$ そのも のの感度よりも排水条件の影響の方が大きいとみるべき である.すなわち, 排水せん断では発生する間隚圧が比 較的すみやかに消散するから申の低下は小さいが, 非排 水せん断では高飽和度状態にあるほど $\phi$ の低下が著しく

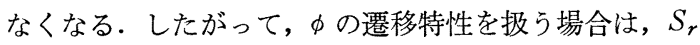
の変化よりもむしろ $S_{r}$ の高いレベルにおける排水条件 に着目すべきである.

一般に， $\phi$ は $S_{r}$ よりむむしろ $e$ の影響を強く受け

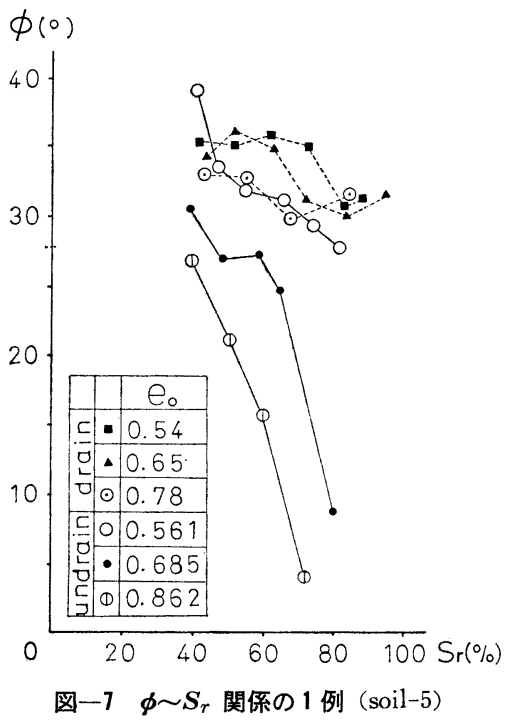

ると考えられる. しかし, 図一7 からは $e$ と $\phi$ の相関 度が高いといえず, 各 $e$ のレベルで e〜申 の遷移特性 も一定の傾向を示さない. このように, фに関しては $e$, $S_{r}$ による遷移特性を特徽的に把握し, 設計に導入する ことは困難である.しかし, 幸いに浅い斜面の破壊問題 では一般に拘束圧が小さいから, 斜面土のせん断強度の 変化に与える $\phi$ の影響は $c$ のそれに比べてはるかに小さ い.したがって, $c-\phi$ 系の山土については, 土の固結度 や種類から申の值を概略推定する方が現実的であり，実 務的にはそれで十分である場合が多い。

\section{3. 斜面保護工の信頼性設計法}

危険斜面を工学の対象とする場合，(i) 降雨生起関 する不確実性, (ii) 斜面状態の推定に伴う不確実性, の 2つを考慮する必要がある.（i）を構造物の設計に導入 した例は水工構造物以外あまりないが，類似の問題とし て突風の生起性を考慮した送電鉄塔の最適設計の例はあ $る^{4)}$. 今後は, 保全対象物の耐用期間との関連で（i）を 設計, 施工のシステム内に導入しなければならなくなる であろう.（ii）で問題となるのは，（主として強度推 定に伴ら不確実性と, (b) 水みちやクラックなど全体の 破壊を支配寸る特異点の推定に伴ら不確実性, である. 本論文で扱ら破壊モードは, 特異点が全体の破壊を支配 する場合ではなく，地層全体を平均的な見地からみてい けばよいすべり破壊を考えているため, ( にのみ議論 を限定する. すなわち, 前章の結果が使用できる問題を 対象にしている.

信頼性設計では，このような不確実性を確率統計的に 扱い, 破壊の可能性を破壊確率で表現することになる. この破壊確率に基づいて, 経済的な評価基準を用いるこ とによって決定を合理的かつ説得的に行いうることが, 信頼性設計の有するもっとも重要な意義である.

\section{（1）降雨と土質係数に関する設計係数の設定}

斜面崩壊に降雨が大きな影響を及ぼすのは事実である が，種々の降雨因子と崩壊との間の詳細な因果関倸はま だ明確になっていない，たとえば，降雨因子としては， 連続雨量, 日雨量, 最大時間雨量, 降雨型などがあげられ る. 本論文では, 土中水分の増加によるすべり破壊に議 論を限定しているので, 降雨因子そのものよりも土中水 分を表わす因子で水文量を扱ら方が有効であ万ら。ま た, 崩壊の時間的な予知問題では, 時々刻々と変わる土 中水分状態の把握が重要となるが, 設計 (決定) 問題に おいては, 降雨による土中の含水比変化を問題にする必 要はなく, その雨によって期待される最大の含水量の状 態を対象にすればよい，すなわち，このような状態の土 
中水分量を評価しうる因子が望ましい，そこで，気象学 で用いられている既往降水指数 (API) の概念 ${ }^{5}$ を参考 にして, 土中水分を表わ寸因子として次にのべる実効雨 量を用いる.

既往降水指数は流域内の土壌水分状態を表わすもの で, 流域からの水分減少率が流域内の水分貯留量に比例 するという考え方に基づいている.いま， $n$ 日前から現 在までの API の総和を $I, n$ 日前の API を $I_{n}$ で表 わすと,

$$
I=I_{0}+K I_{1}+K^{2} I_{2}+\cdots+K^{n} I_{n} \cdots
$$

なる式が成立つ. 式 (6) で $K$ は減少係数を表わす. 降 雨と API の関係の概念図を図一8に示す.ところで, 実際には降雨量から表面流出量を除いた残りが，土壌水 分に効いているはずであるから, 土中に浸透する雨水に 対して API を適用すべきである.そこで，各日ごとの 浸透率 (=浸透量/総雨量) $i$ をかけて, 当日の実効 API を表わすことにする.すなわち，実効 API $\left(I_{e}\right)$ は，

$$
I_{e}=i_{0} I_{0}+i_{1} K I_{1}+i_{2} K^{2} I_{2}+\cdots+i_{n} K^{n} I_{n} \cdots \cdots(7)
$$

なる形で表わされるわけである. いま, 式 (7) の API として日雨量 $R$ を用いると, 実効雨量 $R_{e}$ は次のよう になる・

$$
R_{e}=i_{0} R_{0}+i_{1} K R_{1}+i_{2} K^{2} R_{2}+\cdots+i_{n} K^{n} R_{n}(\mathrm{~mm})
$$

本論文では, 斜面崩壊に寄与する水文量として, 式 (8) で表わされた実効雨量 $R_{e}$ を用いることにする．

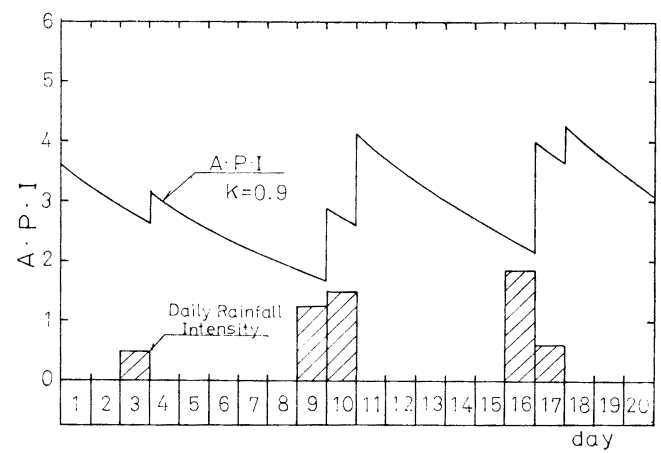

図一8 既往降水指数 API の図（川畑による

減少係数 $K$ は, 一般に地域と季節の関数として表わ されるが,シルト系の土質よりなる斜面では 0.7 程度が 適当とされている ${ }^{6)}$. 浸透率 $i$ にいては, 次の上うに 考える. いま, 地表面に湛水が生ずる限界日雨量を $R_{c r}$ とすると，(i) $R_{c r} \geqq R$ のときに雨水はすべて土中に浸 透し，(ii） $R_{c r}<R$ のときに湛水が起こる. したがっ て，(i) の場合に $i=1$ となり，(ii) の場合に $i=R_{c r}$ l $R$ となるわけである. $R_{c r}$ は湛水が生じる瞬間の浸透 量を日雨量の単位に直したもので, 次のように考えたわ けである.すなわち, いま, 湛水が生じる瞬間に, 地表 面のごく近傍は飽和状態になっていると考えられる. そ
の時の雨水の浸透は, 原理的には飽和状態にある湛水深 零の鉛直土柱における浸透と同じになると考えられるか ら, その時の動水勾配は 1 に等しくなり, 単位時間当た りの浸透量が透水係数に等しくなるわけである.したが って， $R_{c r}$ は土の透水係数 $k(\mathrm{~cm} / \mathrm{sec})$ を日雨量の単位 で表わした次式より求められる.

$$
R_{c r}=8.64 \times 10^{5} k(\mathrm{~mm} / \text { day })
$$

$k$ の值は経験的に類推するか, あるいは現場の土質調 查から求めればよい.

実効雨量 $R_{e}$ は, 既往の降雨データから次のようにし て設計に用いる. すなわち, 斜面崩壊は数年, あるいは 数十年に 1 度の集中豪雨時に発生するのがほとんどだか ら, 設計に用いる水文量としては年極值に着目すればよ いことになる. 水文量として実効雨量を用いる場合, 減 少係数との関係より実効雨量は 1 週間程度の期間を対象 とすれば十分である. いま， 1 週間を 1 ユニットとして 1 年間を約 52 のユニットに分割する. 各ユニットにお いて実効雨量の生起が独立であると仮定すれば， 1 年間 の標本数が大きいから, 実効雨量の年最大值の分布はガ ンベル分布に従うものと仮定してもよいであろう.そこ で, 過去のデータより $R_{e}$ の年最大值を求め, ガンベル 法に基づく再現期間, 生起確率を設計に導入する. ガン ベル分布を求める手順は, 水文学の分野では非常に常識 的なことがらなので，ここではその詳細は他の文献を参 照されることにする7). 1 例として, 岐阜県下山地区で の過去 35 年のデータをもとにして, 砂質ローム斜面 $\left(k=8.2 \times 10^{-4} \mathrm{~cm} / \mathrm{sec}\right) \quad$ について実効雨量の再現期間を 求めたものが表一2 である.

表一2 実効雨量の再現時間 (下山地区)

\begin{tabular}{c|l|c||c|c|c}
\hline $\begin{array}{c}\text { 再現期間 } \\
\text { (年) }\end{array}$ & 超過確率 & $\begin{array}{c}\text { 実効雨量 } \\
(\mathrm{mm})\end{array}$ & $\begin{array}{c}\text { 再現期間 } \\
\text { (年) }\end{array}$ & 超過確率 & $\begin{array}{c}\text { 実効雨量 } \\
(\mathrm{mm})\end{array}$ \\
\hline 10 & 0.1 & 277.0 & 150 & 0.0067 & 435.6 \\
30 & 0.0333 & 342.4 & 200 & 0.005 & 452.4 \\
50 & 0.02 & 372.2 & 300 & 0.0033 & 476.4 \\
70 & 0.0143 & 391.7 & 500 & 0.002 & 505.3 \\
100 & 0.01 & 412.4 & & & \\
\hline
\end{tabular}

次に土質諸係数についての設計条件をみてみる. 斜面 安定に及ぼす浸透水の影響としては, 土の強度低下と自 重の増大を考える. 間嚐圧上昇については取扱わない。 これは, 間隚圧発生の機構が明確でないことに加え, こ こでは問題にしている斜面（主として自然斜面）が多種 多様であり, 有効応力を用いての議論が意味をもつほど に他の要因や条件の精度がよくないからである。いま, 斜面の初期飽和度を $S_{r i}$, 斜面の表層厚 $D(\mathrm{~cm})$, 間偿率 を $n$ とすると, 再現期間 $T$ 年の降雨を対象としたとき の設計飽和度 $S_{r T}(\%)$ は, 次のようにして求める。実 効雨量 $\operatorname{Re}(\mathrm{mm})$ が深さ $D(\mathrm{~cm})$ で間隚率 $n$ の土中に 保持されるわけであるから, 飽和度の増加分は実効雨量 
を $\mathrm{cm}$ 単位に直したものを $n \cdot D$ で除し，それを百分率 で表わす，すなわち，次式のように表わされる.

$$
S_{r T}=S_{r i}+\frac{10 R_{e}}{n D}(\%)
$$

設計では式 (10) の $S_{r T}$ に応じた単位体積重量, 強 度係数を用いて安定解析を行えばよいことになる.すな わち, 強度係数 $c, \phi$ としては, $S_{r T}$ なる飽和度の状態 でのせん断試験より得られた值を用いればよい.このと き，多くのせん断試験によって $c ， \phi$ の分布を求めるの が不経済あるいは非現実的である問題では, 数個の試験 值から平均值のみを求め, 分布型については従来の研究 結果より $c, \phi$ の変動係数 $V_{c}=0.2 \sim 0.4, V_{\phi}=0.1 \sim$ 0.2 を参考にして正規分布を採用する ${ }^{8)}$.さらに，せん 断試験を行わないときには，1.で述べた方法からcの 分布を推定し, $\phi$ は一定值とおけばよい. 単位体積重量 は $S_{r T}$ を用い，確定值として与えることで十分である. なぜなら, 単位体積重量 $\gamma_{t}$ の変動係数は $c, \phi$ のそれ に比べて1オーダー低いからである21,99.

\section{（2）安定解析の方法亡対策工}

ここでは, 実効雨量 $R_{e}$ が与えられた時の条件つき破 壊確率を求めようとしている。すなわち， $R_{e}$ を用いて 式 (10) より計算された飽和度 $S_{r T}$ に対応する設計係 数 $c, \phi, \gamma_{t}$ と斜面形状より, 円弧すべり面法を用いて安 定解析を行い, 設計で必要な斜面の破壊確率 $P_{F}$ を求め るわけである. 具体的にいえば，まず $c ， \phi$ の分布型(正 規分布）から乱数により 1 組の（ $(c, \phi)$ を選び出し，こ れを斜面にわりつけ, 安定解析により安全率 $F$ を求め る. $F$ は抵抗モーメントと転倒モーメントの比で与え る. 多数回この操作をくり返し， $F$ に関して多くの值 を得る.それぞれの $F$ の值は， $F$ の母集団より任意抽 出されたものと考えて，Fの母集団分布を推定する. いま, $F$ の実現值を $x_{i}$ とし, サンプル数を $N$ とする. $c, \phi$ が正規分布するので $F$ の母集団も正規分布すると 考えてよい(10). その平均 $\mu$, 標準偏差 $\sigma$ は次式によって 与えられる。

$$
\left.\begin{array}{l}
\mu=\sum_{i=1}^{N} x_{i} / N \\
\sigma=\sqrt{\sum_{i=1}^{N} x_{i}{ }^{2} / N-\left(\sum_{i=1}^{N} x_{i} / N\right)^{2}}
\end{array}\right\}
$$

そして, $x$ の確率密度関数 $f(x)$ は,

$$
f(x)=\frac{1}{\sqrt{2 \pi} \sigma} \exp \left\{-\frac{(x-\mu)^{2}}{2 \sigma^{2}}\right\}
$$

で表わされるので, 斜面の破壊確率 $P_{F}$ は次のように なる。

$$
\begin{aligned}
P_{F}= & \int_{-\infty}^{1} f(x) d x=\frac{1}{\sqrt{2 \pi} \sigma} \\
& \cdot \int_{-\infty}^{1} \exp \left\{-\frac{(x-\mu)^{2}}{2 \sigma^{2}}\right\} d x
\end{aligned}
$$

次に，崩壊防止工としては種々のものが考えられる が，ここでは力学的評価が可能で，一般的なものとし て，(i）土留擁壁，(ii) 切土，を考えてみる.もちろ ん, 他の種々の防止工に対しても以下に示寸設計の基本 的な考方方は変わらない.さて，(i) は抵抗力の増大に， (ii) は破壊力の減少に寄与する. 擁壁の効果は, 擁壁に よって生ずる抵抗力 $P$ をすべり土塊に作用させて安定 解析（力のつり合い計算）を行うことにより評価する. また，擁壁によって新たに生ずる抵抗力 $P$ は，推壁底 面の摩擦抵抗力と擁壁前面の土かぶりの部分の受働抵抗 力の $1 / 3$ よりなるものと考える.すなわち， $P$ は次式で 計算される.

$$
\begin{aligned}
P= & c B+W \tan \phi \\
& +\frac{1}{3}\left(\frac{1}{2} \gamma_{t} D_{f}{ }^{2} N_{\phi}{ }^{2}+2 c D_{f} N_{\phi}\right)
\end{aligned}
$$

ここに, $B$ は擁壁の底面幅, $W$ は擁壁の重量, $D_{f}$ は 擁壁前面の土かぶり梁さであり, $N_{\phi}=\tan \left(45^{\circ}+\phi / 2\right)$ で ある。

\section{（3）構造物の耐用期間を考慮した設計法}

一般に, 水位, 流量, 降雨量などの水文量の再現期間 とは, 「水文量の既往の観測值について, 各年の極值を 統計的に処理し, ある大きさの年極值が何年に一度出現 する確率を有するかを求め, その年数をもって再現期間 といら $\left.{ }^{11}\right\lrcorner$ と定義され，その年数は，「その年極值を越

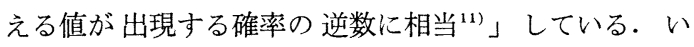
ま, 年極值として年最大值をとり, 再現期間 $T$ 年の水 文量を $x_{T}$ と表わすと, 任意の年の年最大值 $X$ が $x_{T}$ を越える確率 $\operatorname{Prob}\left(X>x_{T}\right)$ は $1 / T$ に等しくなる. し たがって，Xが $x_{T}$ 以下となる確率は次式で表わされ る.

$$
\operatorname{Prob}\left(X \leqq x_{T}\right)=1-1 / T
$$

次に, 構造物の耐用期間を $t$ 年とする. 構造物を設計 寸る際に基準となるべき設計水文量としては, 構造物の 耐用期間との関連より, 耐用期間内に発生する最大の水 文量を採用すべきである. そこで, 耐用期間 $t$ 年内に生 起する最大水文量を $X_{t}{ }^{*}$ (確率変数) とする.阁藤 ${ }^{12}$ によ れば，耐用期間内の各年最大水文量 $X$ が，すべて $x_{T}$ 以下となる確率は, $X$ の母集団から $t$ 回任意抽出し, 各回とも $X$ の值が $x_{T}$ 以下となる確率となる.これは, とりもなおさず $X_{t}{ }^{*}$ が $x_{T}$ 以下となる確率を意味して いる.したがって, $t$ 回の任意抽出が独立であると仮定 すれば， $X_{t}^{*}$ が $x_{T}$ 以下となる確率は次式で与えられ ることになる。

$$
\operatorname{Prob}\left(X_{t}^{*} \leqq x_{T}\right)=\left\{\operatorname{Prob}\left(X \leqq x_{T}\right)\right\}^{t}
$$

式 (15), (16) より, 次式が得られる.

$\operatorname{Prob}\left(X_{t}^{*} \leqq x_{T}\right)=(1-1 / T)^{t}$ 
設計においてわれわれが知りたいのは，式（17）のよ らに $T$ の関数として表わされた $X_{t}^{*}$ の確率ではなく, $X_{t}^{*}$ の值そのものがどのように分布しているかである. そこで, 再現期間 $T$ と $x_{T}$ の関係を用いて, 変数を $T$ から $x_{T}$ に変換することにする. 年最大值の分布型には いろいろな形式のものがあるが，ここでは前節との関連 よりガンベル分布を仮定する.ガンベル分布の詳細につ いては他の文献》を参照されることにして，その一般形 だけを示そう。ガンベル分布に扔いて， $T$ と $x_{T}$ には 次のような関係がある.

$$
\left.\begin{array}{rl}
1-\frac{1}{T} & =\exp \left(-e^{-y}\right) \\
y & =a\left(x_{T}-x_{0}\right)
\end{array}\right\}
$$

ここに， $a, x_{0}$ は既往の年最大水文量の観測值より得ら れるパラメーターである. この式 (18) を式 (17) に代入 すると， $X_{t}^{*}$ が $x_{T}$ 以下となる確率は次式のようにな る.

$\operatorname{Prob}\left(X_{t}^{*} \leqq x_{T}\right)=\left[\exp \left\{-e^{-a\left(x_{T}-x_{0}\right)}\right\}\right]^{t} \cdots$ (19) 式 (19) より, $t$ 年の耐用期間内に発生する最大水文量 $X_{t}^{*}$ の分布関数 $F\left(x_{t}^{*}\right)$ は, 次式で与えられることが わかる.

$$
F\left(x_{t}^{*}\right)=\operatorname{Prob}\left(X_{t}^{*} \leqq x_{t}^{*}\right)=\left[\exp \left\{-e^{-a\left(x_{t}^{*}-x_{0}\right)}\right\}\right]^{t}
$$

$X_{t}{ }^{*}$ の確率密度関数は式 $(20)$ を $x_{t}$ * で微分すれば, $f\left(x_{t}^{*}\right)=a t e^{-a\left(x_{t} t^{*}-x_{0}\right.},\left[\exp \left\{-e^{-a\left(x_{t}^{*}-x_{0}\right)}\right\}\right] t$

のようになる. $f\left(x_{t}^{*}\right)$ をさらに $x_{t}{ }^{*}$ で微分すると，

$$
\begin{aligned}
\frac{d f\left(x_{t}^{*}\right)}{d x_{t}^{*}}= & a t e^{-a\left(x_{t} t^{*} x_{0}\right)}\left[\exp \left\{-e^{-a\left(x_{t}^{*}-x_{0}\right)}\right\}\right]^{t} \\
& \cdot\left\{1-t e^{-a\left(x_{t}{ }^{*}-x_{0}\right)}\right\} \ldots \ldots \ldots \ldots \ldots . . .
\end{aligned}
$$

となる. $d f\left(x_{t}^{*}\right) / d x_{t}^{*}=0$ となるのは, 式 (22) より，

$$
\frac{1}{t}=\exp \left\{-a\left(x_{t}^{*}-x_{0}\right)\right\}
$$

のときである. いま, 再現期間 $t$ 年の水文量 $x_{t}$ と $t$ の 間には次の関係が存在する.

$$
1-1 / t=\exp \left\{-e^{-a\left(x_{t}-x_{0}\right)}\right\}
$$

式 $(24)$ より， $x_{t}$ を求めると次のようになる.

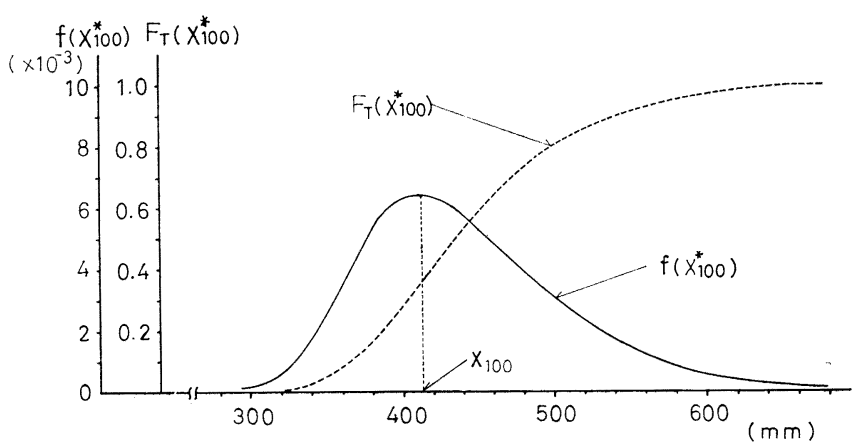

図一9 $X_{100} *$ の分布関数 $F_{T}\left(X_{100} *\right)$ と確密密度関数 $f\left(X_{100} *\right)$

$$
x_{t}=-\frac{1}{a} \ln \left\{-\ln \left(1-\frac{1}{t}\right)\right\}+x_{0} .
$$

一般に, $t$ の值が大きいときに，

$$
\ln \frac{1}{t} \fallingdotseq \ln \left\{-\ln \left(1-\frac{1}{t}\right)\right\}
$$

となるから，この関係により式 (25) は次のようになる.

$$
x_{t}=-\frac{1}{a} \ln \frac{1}{t}+x_{0}
$$

ところで, 式 (23) を $x_{t}$ * について解くと次式のよう になる。

$$
x_{t} *=-\frac{1}{a} \ln \frac{1}{t}+x_{0}
$$

したがって，式 (27),(28) より $f\left(x_{t}^{*}\right)$ が最大とな る $\left(X_{t}^{*}\right.$ の確率密度がもっとも高くなる $)$ のは, 耐用期 間 $t$ 年に発生する最大水文量 $x_{t} *$ が，耐用期間に等しい 再現期間の水文量 $x_{t}$ と等しくなるときであることがわ かる.これは,耐用期間内に発生する水文量の最大值とし ては, 耐用期間と等しい再現期間をもつ水文量がもっと むおこりやすいことを意味しており，また， $X_{t} *$ が $x_{t}$ の近傍でピークとなって広く分布することが式 (21) よ り知られる. そこで, 一例として耐用期間を 100 年とし たときに，前節で述べた下山地区の実効雨量の，耐用期 間内に発生する最大值の分布関数 $F\left(x_{100}{ }^{*}\right)$, 密度関数 $f$ $\left(x_{100} *\right)$ (ここに, $x$ は実効雨量を示す) を 図一9 に示 す.図一9より， $f\left(x_{100} *\right)$ は $x_{100}$ *でほぼピークとなって おり，広い範囲に分布していることがわかる. 耐用期間 を考えて設計を行う場合に，設計水文量を単に恣意的に 選ぶのではなく, 式 (21) で表わされるような理論的根 拠をもった確率分布として設計に導入すべきことは自明 であろう。

次に，耐用期間内に構造物が破壊する確率は，ある大 きさの最大水文量が生ずる確率と，その水文量により構 造物が破壊する確率の積を, 最大水文量の確率空間で積 分したものとなる.この耐用期間を考慮した破壊確率を $P_{F}{ }^{*}$ と表わすと, $P_{F}{ }^{*}$ は次のようになる，いま，耐用 期間 $t$ 年の最大水文量 $x_{t}$ * によって, 構造物が破壊す る確率を $P_{F}\left(x_{t}^{*}\right)$ とすると, $P_{F}^{*}$ は $f\left(x_{t}^{*}\right)$ と $P_{F}$ - $\left(x_{t}^{*}\right)$ より次式のように表わされる.

$$
P_{F}^{*}=\int_{\left\{x_{t}^{*}\right\}} P_{F}\left(x_{t}^{*}\right) f\left(x_{t}^{*}\right) d x_{t}^{*}
$$

ここに, $\left\{X_{t}^{*}\right\}$ は $X_{t}^{*}$ の確率空間を表わす.

このようにして, 式 (29) より求められた $P_{F} *$ を用いて，構造物の耐用期間を考虑した 信頼性設計を行うわけである.ここで, 最適設 計とは，必要な全費用 $C_{T}$ を最小にするもので あるという経済的評価基準を採用する. 構造物 の建設費 $C_{c}$, 破壊損失費 $C_{F}$, および耐用期間 
を考慮した破壊確率 $P_{F}{ }^{*}$ より, $C_{T}$ は次式によって表 わされる(13).

$$
C_{T}=C_{c}+P_{F} * C_{F}
$$

最適設計としては， $C_{T}$ を最小にするものを選べばよ い.なお，これまでに展開してきた議論は水文量だけで なく, 年最大值の分布型がわかっている他の現象に対し ても応用できるものである. また, 実際の計算では, 式 （29）を数值積分することによ って $P_{F} *$ を求めればよい.

\section{4. 最適対策工法決定に 関する事例研究}

ここでは，これまでに述べて きた方法論を具体的に説明する ために, 特定の斜面を対象にし た例ではあるが，実際問題に適 用してその結果に基づき現実に 施工した事例について述べる. 主たる保全対象物は, 斜面上部 にある大型送電用鉄塔である.

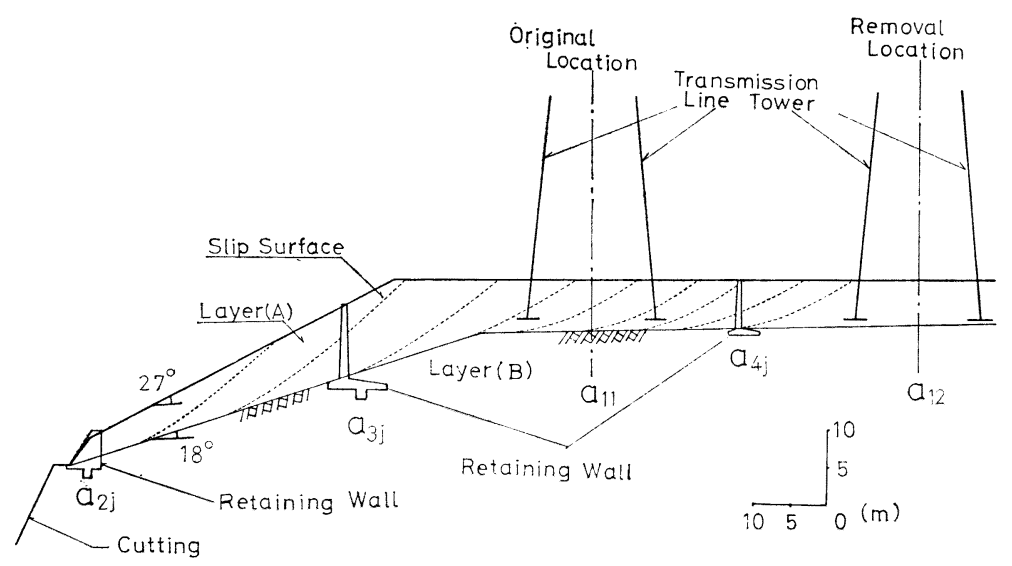

\section{図一10 斜面と鉄塔の概況}

\section{（1）斜面および鉄塔の概況}

問題となる斜面のもっとも危険な縦断面図を鉄塔の位 置とともに 図一10 に示す. 斜面下部は採石場となって いて, もとの地形が採石により急峻な状態に変化したこ とが，斜面不安定化の素因となっている. 図一11 の集 中豪雨時に, 当斜面の数個所にクラックが現われ, 鉄塔 上部構造に限界量に近い変形が生じた. その後, 斜面は 不安定下の一時的な静止状態を保っていたが, 再度多量 の降雨があれば崩壊の危険性は十分考えられた.この斜 面で特に問題となったのは, 図一10 中の A 層 である．地盤調查により，地山の滑動はこの層 内か, あるいはB層（風化頁岩）との境界付近 で生ずるものと考えられた.土質試験の結果, $\mathrm{A}$ 層は砂質ローム土よりなり, 間幥比 $e=0.96$, 比重 $G_{s}=2.63$, 通常の状態での自然含水比 $w_{n}$ $=23.2 \%$, 飽和度 $S_{r}=64 \%$, 透水係数 $k=8.2$ $\times 10^{-4}(\mathrm{~cm} / \mathrm{sec})$ であった。 また, 強度係数 $c$, $\phi$ については, $c$ の平均值 $\mu_{c}=10.3-0.1 S_{r}$ $\left(\mathrm{t} / \mathrm{m}^{2}\right), \phi$ の平均值 $\mu_{\phi}=10^{\circ}$, 標準偏差 $\sigma_{c}=0.4$ $\mu_{c}, \sigma_{\phi}=1.78^{\circ}$ であることが判明した．B 層は 含水比 $32 \%$ で, $k=1.1 \times 10^{-6}(\mathrm{~cm} / \mathrm{sec}), \mu_{c}=$ $7.0\left(\mathrm{t} / \mathrm{m}^{2}\right), \mu_{\phi}=20^{\circ}$ の風化頁岩である.

$\mathrm{B}$ 層は $\mathrm{A}$ 層に比べ透水係数が非常に小さいの で雨水の浸透は $\mathrm{A}$ 層に限られると考えてよい. このA層内の浸透性を知る目的で, 室内鉛直浸 透実験を実施した．装置の概要を図一12(a) に示すまま た降雨パターンは同図 (b) に示されているが, これは 図一11 における降雨の初期 1 日程度を単純化したもの である、降雨は装置上部のノズルで与えた。図一12(c) に浸透状況を示す. 土中の飽和度測定は実験開始前と終 了直後について行い, 浸透の進行は浸潤前線(図一12(c) の破線）より推定した.この結果, 深さ $1.8 \mathrm{~m}$ 程度の

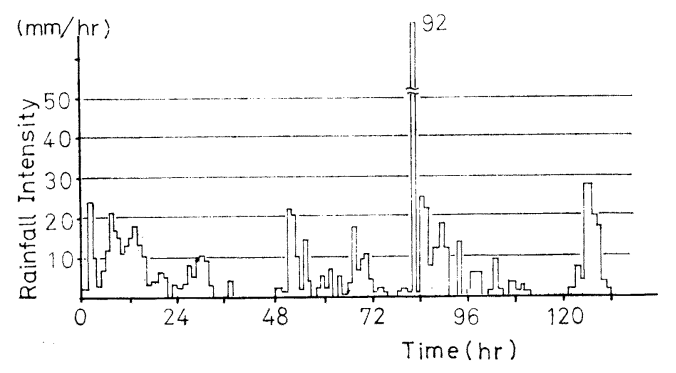

図ー11 集中豪雨のハイエトグラフ

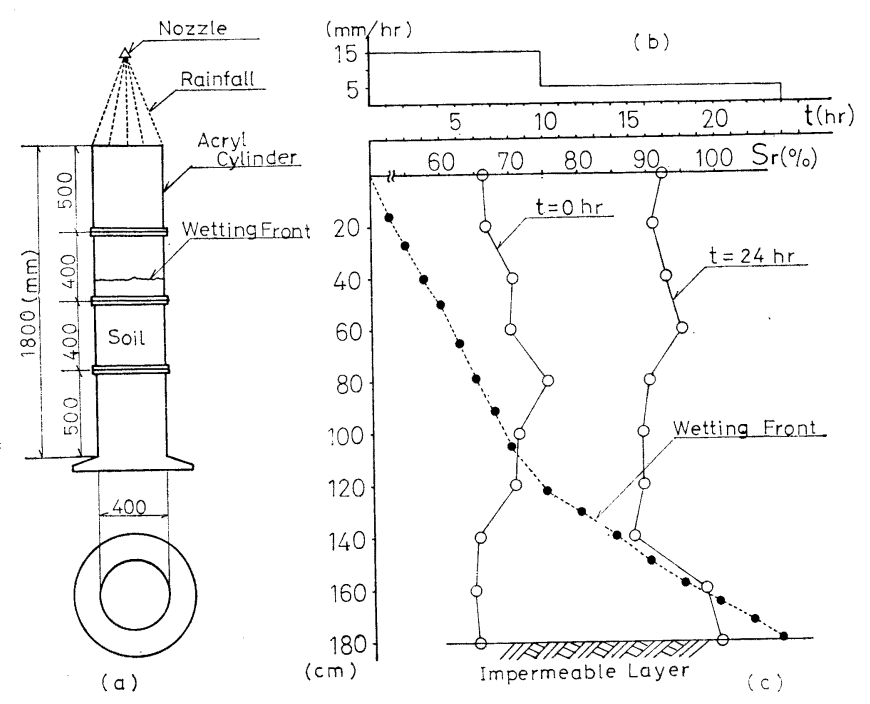

図一12 鉛直漫透実験の概要と結果 
表層では浸潤前線は 1 日弱で基層に到達することが判明 した. したがって, 図一11 の雨量と期間を有する降雨 が生起すれば, 最大表層厚 $8 \mathrm{~m}$ 程度の $\mathrm{A}$ 層は, 全層厚 にわたって降雨浸透の影響を受けることが予想された。

また, 図一12(c) は, 浸透後の土中の飽和度が深さ方向 にほぼ一様に分布すると仮定して妥当であることを示し ている.

\section{（2）斜面の安定性の検討}

当該斜面では，限界日雨量は $k=8.2 \times 10^{-4}(\mathrm{~cm} / \mathrm{sec})$ から式 (9) を用いて $R_{c r}=708.5(\mathrm{~mm})$ となる. また， 表層厚は一定でないため, 換算表層厚として $D_{e}=A / L$ を用いると $D_{e}=4.7 \mathrm{~m}$ となる. ここに, $L$ 淆壊予想 部分の斜面長を, $A$ は断面積を表わす. 図一11 に示す 集中豪雨を実効雨量 $R_{e}$ で表わすと, $R_{e}=415 \mathrm{~mm}$ とな り, 表一2 よりおよそ 100 年再現期間の実効雨量に相当 するもので, 斜面 A 層の飽和度 $S_{r}=82 \%$ と計算され た.

斜面の安定解析を行う場合, 図一10 において点線で 示されるような小崩壊が連続し, 鉄塔脚部に達したとき をもって鉄塔の破壊と定義する. 計算の結果, 当該斜面 に図一11の集中豪雨が降ったとき, 斜面の破壊確率 $P_{F}=22.36 \%$ にまで上昇していたことが判明した.こ れより，当斜面を現状のままで放置した場合の危険度
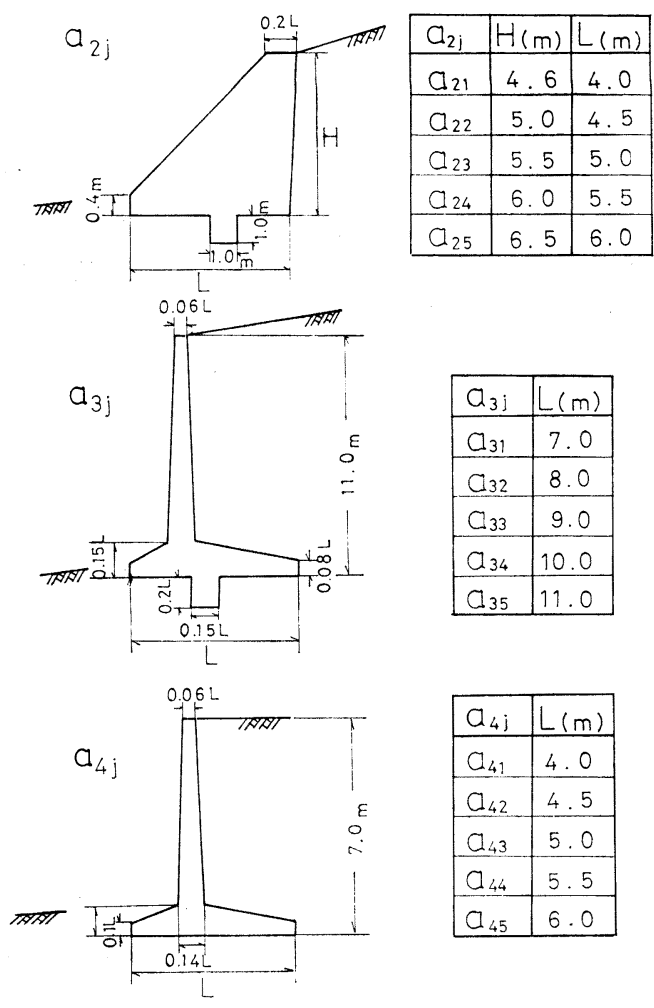

図一13 各対策工の諸元
は，公共性の高い構造物として許容される值よりはるか に高く, 早急な対策工を構ずる必要が生じたのである.

現実的，技術的見地より，鉄塔防護のために検討され るべき対策工（action という意味で $a_{i j}$ で表わす）は， 種々の議論の結果, 次のようになった.

(i ) $a_{1 j}$ : これは鉄塔を現地点でたてかえるか（ $a_{11}$ で表示)，あるいは別の地点に移設する ( $a_{12}$ で表示) 場 合の鉄塔本体工事を表わす．鉄塔の上部構造は，斜面の 変形による不同変位のために許容応力限界を越え，目で みてもわかるほど変形していたので，たとえ現地点に鉄 塔を残す場合でもたてかえが必要となったのである.

(ii) $a_{2 j}$ :この対策工は, 斜面のり先に重力式擁壁 を建設し，斜面崩壊そのものを防止する目的をもつ. $j$ は各擁壁の断面形に相当するものを表わす（図一13）.

(iii) $a_{3 j}$ : 現位置の鉄塔基礎を $\mathrm{L}$ 型擁壁で防護する ための対策工であり，5種類の断面を考えた（図一13）.

(iv) $a_{4 j}$ : 鉄塔移設の場合に, 移設地点付近に L 型 擁壁を建設し，鉄塔基礎を防護する目的で建設されるも ので, $a_{3 j}$ と同様に 5 種類の断面について検討が行われ た (図-13).

上述の各対策工の組合わせにより, 合計 22 種類の対 策工案が考えられ, 個々について安定解析が行われた.

\section{（3）最適対策工の決定}

対策工決定のための評価規準としては, 経済的評価モ デル式 (30) を用い， $C_{T}$ が最小となる対策工を最適な ものと考えた. 式 (30) における, $C_{c}, P_{F}^{*}, C_{T}$ はいず れも各対策工の関数として表わされる.したがって,

$$
C_{T}\left(a_{i j}\right)=C_{c}\left(a_{i j}\right)+P_{F} *\left(a_{i j}\right) C_{F} .
$$

と書ける.

初期建設費用 $C_{c}\left(a_{i j}\right)$ 法次のように計算される.

(i) $C_{c}\left(a_{1 j}\right)$ : これは, 鉄塔解体撤去費, 仮鉄塔工 事費, 鉄塔本体工事費よりなる.

(ii) $C_{c}\left(a_{2 j}\right)$ : この費用は, 斜面先に建設される重 力式擁壁の大きさによって決定される. 重力式掊壁の施 工費は, 擁壁の体積に比例すると考えた. 本章では, 平 面図を省略しているが, この案の場合, 擁壁の建設延長 は $45 \mathrm{~m}$ になったので, 費用注次式で計算された.

$$
C_{c}\left(a_{2 j}\right)=c_{21} \times 45 \times V_{2 j}+c_{22}
$$

ここに, $c_{21}$ は重力式擁壁の施工単価, $V_{2 j}$ は擁壁延長 $1 \mathrm{~m}$ 当たりの体積, $c_{22}$ は採石現場ののり面保護, 伐採 および土地補償に必要な費用である.

(iii) $C_{c}\left(a_{3 j}\right)$ : この費用は, $a_{2 j}$ と同様に $\mathrm{L}$ 型擁壁 の大きさによって決定されるもので, 次式によって表わ された.

$$
C_{c}\left(a_{3 j}\right)=c_{31} \times 44 \times V_{3 j}+c_{32}
$$

ここに, $c_{31}$ は L型擁壁の施工単価, $V_{3 j}$ はL型擁壁の 
表一3 各対策工の施工費

\begin{tabular}{|c|c|c|c|c|c|}
\hline 記号 & 施工費の内容 & 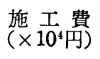 & 記号 & 施工費の内容 & 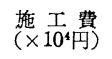 \\
\hline$c_{21}$ & $\begin{array}{l}\text { 重力式擁壁の } \\
\text { 施 工 单 価 }\end{array}$ & $6.8\left(/ \mathrm{m}^{3}\right)$ & $c_{31}$ & $\begin{array}{l}\mathrm{L} \text { 型㩁壁の } \\
\text { 施笚価 }\end{array}$ & $15.65\left(/ \mathrm{m}^{8}\right)$ \\
\hline$c_{22}$ & $\begin{array}{l}\text { のり面保護費 } \\
\text { 土地補償費 }\end{array}$ & 1048 & $c_{32}$ & $\begin{array}{l}\text { 伐採, 土地 } \\
\text { 補 }\end{array}$ & 524 \\
\hline
\end{tabular}

単位延長当たりの体積， $c_{32}$ は伐採および土地補償費で ある.なお，L型擁壁の建設延長は $44 \mathrm{~m}$ であった.

(iv) $C_{c}\left(a_{4 j}\right): C_{c}\left(a_{3 j}\right)$ と同様, 式 (33) の形で表わ される.

計算に用いた $c_{21}, c_{22}, c_{31}, c_{32}$ の值は 表一3 に示され ている.これらの值は, 昭和 51 年度の実績をもとに割 出されたものである。

一方, 破壊損失費 $C_{F}$ は, 鉄塔倒壊による損失と復 旧工費よりなる．鉄塔倒壊による損失としては，（i）停 電による販売電力料金のロス，(ii）停電に伴う社会的損 失, (iii) 送電系統切替に伴う送電ロス分, (iv) 予備設 備（たとえば，通常は稼動していないが，事故のとき働 く発送電設備）の待機損失等が考えられる.この中で評 価がむずかしいのは（ii）の社会的損失であるここで は，スウェーデンで行われた計算例 ${ }^{14)}$ を参考にして，口 ス電力料金（i）の 20 倍とした. 電源容量 $1500 \mathrm{MW}$ $\left(1 \mathrm{MW}=10^{6} \mathrm{~W}\right)$, 停電時間 30 分, 送電線復旧に要する 期間 100 日といら条件（この条件は当該送電線にみあっ たものである）で鉄塔倒壊による損失を見積ると， 6.24 $\times 10^{8}$ 円となった.

復旧工費としては, 鉄塔の再建費, 基礎防護費, 用地 費, ケーブル費が考えられ，鉄塔 1 基当たりで復旧工事 費は，1.8 $10^{8}$ 円となった。1つの鉄塔が倒壊すると， 実際にはその前後の鉄塔が引きずられて影響を受け，結 局, これらの鉄塔のたてかえも必要となる場合があるの で, (a) 破壊が 1 基に限られるケース，(b) 前後の鉄塔の たてかえも必要となるケース, の 2 つの場合について計 算した. ケース (b)゙は, 復旧工費がケース @の 3 倍と なる.

超高圧鉄塔の耐用期間は 100 年ぐらいと考えるのが一 般的であるから， $t=100$ とおく.この耐用期間を考慮 して設計計算を行った結果，各対策工案ですべて耐用期 間を考慮した破壊確率 $P_{F} *$ は, 再現期間 $T=130$ 年程 度の実効雨量に対する破壊確率に相当していることが判 明した．また，各対策工案について， $P_{F}{ }^{*}$ と $C_{T}$ の関 係を 表-4 に示しているが，ケース (a)，(b) の両方とも， $C_{T}$ が最小となる最適解は, 対策工案 $a_{12}$ と $a_{41}$ を組合 わせた案となり，現実にこのように実施されたすなお ち，最適工案として，鉄塔を移設しその基礎を $\dot{a}_{41}$ に示 す断面の 擁壁で防護する案が選択されたのである。な お, 以上の結果より，送電鉄塔の 耐用期間を考える場
表-4 各対策工案の $\boldsymbol{P}_{F}{ }^{*}, C_{T}, C_{c}$

\begin{tabular}{|c|c|c|c|c|}
\hline \multirow{2}{*}{ 対策工案 } & \multirow{2}{*}{$\begin{array}{l}\text { 初期建設費用 } \\
C_{c}\left(\times 10^{4} \text { 円) }\right.\end{array}$} & \multirow{2}{*}{$\begin{array}{c}\text { 耐用破壊確率 } \\
P_{F}{ }^{*}\end{array}$} & \multicolumn{2}{|c|}{ トータルコスト $C_{T}\left(\times 10^{4} 円\right)$} \\
\hline & & & ケース (a) & ケース (b) \\
\hline$a_{11}$ & 10866 & 0.2483 & 30868 & 39315 \\
\hline$a_{11} \quad a_{21}$ & 15598 & 0.0948 & 23235 & 26460 \\
\hline$a_{11} \quad a_{22}$ & 16351 & 0.0741 & 22320 & 24841 \\
\hline $\begin{array}{ll}a_{11} & a_{23}\end{array}$ & 17269 & 0.0558 & 21764 & 23662 \\
\hline$a_{11} \quad a_{24}$ & 18279 & 0.0414 & 21614 & 23022 \\
\hline$a_{11} \quad a_{25}$ & 19380 & 0.0287 & 21692 & 22668 \\
\hline$a_{11} \quad a_{31}$ & 21498 & 0.1216 & 31293 & 35431 \\
\hline$a_{11} \quad a_{32}$ & 23682 & 0.0714 & 29434 & 31863 \\
\hline$a_{11} \quad a_{33}$ & 26050 & 0.0382 & 29127 & 30427 \\
\hline$a_{11} \quad a_{34}$ & 28605 & 0.0187 & 30111 & 30748 \\
\hline$a_{11} \quad a_{35}$ & 31346 & 0.0083 & 32015 & 32297 \\
\hline$a_{12}$ & 13224 & 0.1234 & 23164 & 27363 \\
\hline$a_{12} \quad a_{21}$ & 17956 & 0.0948 & 25593 & 28818 \\
\hline$a_{12} \quad a_{22}$ & 18709 & 0.0741 & 24678 & 27199 \\
\hline$a_{12} \quad a_{23}$ & 19627 & 0.0558 & 24122 & 26020 \\
\hline$a_{12} \quad a_{24}$ & 20637 & 0.0414 & 23972 & 25380 \\
\hline $\begin{array}{ll}a_{12} & a_{25}\end{array}$ & 21738 & 0.0287 & 24050 & 25026 \\
\hline $\begin{array}{ll}a_{12} & a_{41}\end{array}$ & 17206 & 0.0034 & (C) 17480 & (C) 17596 \\
\hline $\begin{array}{ll}a_{12} & a_{42}\end{array}$ & 17889 & 0.0017 & 18026 & 18084 \\
\hline$a_{12} \quad a_{43}$ & 18629 & 0.0009 & 18701 & 18732 \\
\hline$a_{12} \quad a_{14}$ & 19418 & 0.0004 & 19450 & 19463 \\
\hline$a_{12} \quad a_{45}$ & 20263 & 0.0002 & 20279 & 20286 \\
\hline
\end{tabular}

（注）は最適解を示す。

合, 実効雨量の生起性は 130 年程度の規模を考えるべき こと，また， $C_{T}$ が最小となるときの $\left(P_{F}^{*}\right)_{0 p t}$ は表一 4 から約 $0.34 \%$ であることがわかったが，これらは今 後送電鉄塔建設において注目されるべき值といえる.

\section{5. おわりに}

本論文は，信頼性理論を用いて斜面崩壊の防止対策を 最適化する手法を提起したものである。 また，斜面崩 壊の力学的機構に関するいくつかの問題を, 現実的に, かつできるだけ簡単に処理する方法も示している. 以下 に，本論文の結論を簡単に列記する.

（1）みかけの粘着力はある飽和度の状態で最大とな り，そのときの飽和度と土の間隍比には直線的関係があ る. また, ピーク粘着力 $c_{\max }$ は土の物理係数 $e, d_{50}$, $U_{c}$ によって推定できる. この新見解により，力学試験 によらずに任意の飽和度での粘着力の分布を推定する方 法が示され，実験值による分布と照合された.

（2）実効雨量の概念により，降雨時の斜面表土の飽 和度を推定し，設計計算に用いる方法が示された。 た, 実効雨量なる 1 つの降雨因子で, 斜面崩壊に関連寸 る水文量の再現期間を設計に導入することが可能となっ た.

（3）構造物の耐用期間と水文量の再現期間の関係よ り耐用期間を考慮した破壊確率を提案し，水文量の生起 性を設計に導入する方法が示された.

（4）斜面上の超高圧大型送電鉄塔の問題を取扱った 
事例研究によって, この方法論が実際問題に適用でき, しかも合理的なものであることを示した.

なお，本研究にあたって適切なご助言を賜わった名古 屋大学助教授 高木不折博士に 深甚なる謝意を表する次 第である.また，士質試験のデータは当研究室卒業生， 渡橋 誠, 夜久正範, 桑原正彦, 倉石謙司, 服部義巳諸 氏が卒業研究で実施されたものの一部を利用させていた だいたことを付記し，感謝の意を表する，計算にあたっ ては名古屋大学大型計算機センター FACOM 230-60 を 用いた。

\section{参考文献}

1）鬼塚克忠: 締固めた不飽和土の間げき圧と力学的性状に 関する実験的研究, 九州大学学位申請論文, 1973.

2）松尾 稔 - 黒田勝彦: 不飽和土の土質諸係数と破壊確率 に関する一考察, 士木学会論文報告集, 第 208 号, pp. 65 $\sim 75,1972$.

3）上野 誠・服部義巳・夜久正範 : 二相流理論を用いた降 雨浸透解析について, 土木学会中部支部研究発表会講演 概要集, pp. 145 146, 1977.

4) Gibson, B.St.C.:Optimum Design Loadings for Major Transmission Lines, CIGRE SC-22, WG-06, 1974.
5）川畑幸夫：水文気象学, 地人書館, pp. 246 247, 1969.

6) 酒井数夫 - 今井篤雄 - 菊 優 : 切取のり面採点表の検 討および降雨時の運転規制の 見直しと実施，鉄道技術研 究所報告, No. 929, pp. 28 31, 1974.

7）金丸昭治 - 高棹琢馬 : 水文学, 朝倉書店, pp. 49 52, 1975.

8) Matsuo, M. : Reliability in Embankment Design, MIT, Dept of Civil Eng Research Report, No. R 7633, pp. 78 87, 1976.

9）松尾 稔・黒田勝彦：盛土建設のための土質調査と盛土 の安定性に関する研究, 土木学会論文報告集, 第 196 号, pp. $75 \sim 86,1971$.

10) 三上 操: 統計的推測, 筑摩書房, pp. $68 \sim 72,1969$.

11）土木用語事典編集委員会編：土木用語辞典，技報堂・コ 口ナ社, p. $579,1974$.

12）斎藤鍊一: 暴風の確率限界值, 気象庁研究時報, $9, \mathrm{pp}$. 529 532, 1957.

13）長尾義三・松尾 稔 - 黒田勝彦: 盛土の設計安全率の決 定に関する研究, 土木学会論文報告集, 第 203 号, pp. $71 \sim 85,1972$.

14) Shipley, R.B., Patton, J.S., Denison, J.S. : Power Reliability Cost Versus Worth, IEEE Transactions, 1972.

(1977.10.6 - 受付) 